\title{
ESQ DAN KEBUTUHAN SPIRITUALITAS CIVITAS AKADEMIK
}

\section{ASEP SOLIKIN}

Dosen Pada Fakultas Keguruan Dan Ilmu Pendidikan Prodi Bimbingan Dan Konseling Universitas Muhammadiyah Palangkaraya

\begin{abstract}
ABSTRAK
Hakikatnya manusia adalah makhluk beragama (homoreligius) dan fithrahnya manusia adalah makhluk spiritual yang selalu berupaya untuk senantiasa ada dalam kondisi mental yang sehat, agar hidup bahagia, lahir dan batin. la memiliki potensi kecerdasan spiritual yang sempurna untuk meraih "spiritual wellness", yaitu kebahagiaan hidup sejati sebagai wujud karunia Ilahi. Untuk itulah layanan Bimbingan dan Konseling sebagai sebuah bentuk hubungan interpersonal seyogyanya berpegang pada nilai-nilai agama saat membantu, mengarahkan, dan memandu individu untuk mengembangkan kecerdasan spiritual hingga menggapai kehidupan bermakna dan kebahagiaan yang utuh dan terpadu. Karena nilai-nilai agama bersifat fundamental, mutlak, dan universal.
\end{abstract}

Kata Kunci: ESQ, Kecerdasan Spiritual

\section{PENDAHULUAN}

Spiritual memiliki kekuatan untuk mentransformasi kehidupan dan bahkan dapat mengubah realitas kehidupan fisik di sekitar kita. Dengan memiliki kecerdasan spiritual berarti kita memahami sepenuhnya makna dan hakikat kehidupan yang kita jalani dan ke manakah kita akan pergi. Jika merujuk pada agama, pada awal penciptaan manusia, Tuhan meniupkan roh atau napas kehidupan kepada manusia. Berarti roh kita adalah sesuatu yang membuat kita hidup. Jadi Roh kita bersumber pada sumber yang sama, yaitu Tuhan yang Mahakuasa. Kita nantinya juga akan kembali menyatu dengan Sang Pemberi Kehidupan. Jadi apa pun agama kita, status sosial ekonomi, suku, ras, golongan, kebangsaan dan tingkat pendidikan kita, tidaklah menjadi yang utama. Menjadi cerdas spiritual berarti mampu melalui batasan atau sekat-sekat tersebut dan menemukan siapa diri kita yang sebenarnya serta tujuan kehidupan kita. Menjadi cerdas spiritual berarti kita lebih memahami diri kita sebagai makhluk spiritual yang murni, penuh kasih, suci, dan memiliki semua sifat-sifat ilahi. Termasuk memiliki kemampuan sebagai pencipta realitas kehidupan yang berkualitas dan berkelimpahan (menjadi co-creator)

Spiritualitas Adalah Kebutuhan Tertinggi Kita. Ahli jiwa termashur Abraham Maslow, dalam Makalah nya Hierarchy of Needs menggunakan istilah aktualisasi diri (self-actualization) sebagai kebutuhan dan pencapaian tertinggi seorang manusia. Maslow menemukan bahwa, tanpa memandang suku atau asal-usul seseorang, setiap manusia mengalami tahap-tahap peningkatan kebutuhan atau pencapaian dalam kehidupannya. Kebutuhan tersebut meliputi: Kebutuhan fisiologis (Physiological), meliputi kebutuhan akan pangan, pakaian, tempat tinggal maupun kebutuhan biologis. Kebutuhan keamanan dan keselamatan (Safety), meliputi kebutuhan akan keamanan kerja, kemerdekaan dari rasa takut ataupun tekanan, keamanan dari kejadian atau lingkungan yang mengancam, Kebutuhan rasa memiliki, sosial dan kasih sayang (Social), meliputi kebutuhan akan persahabatan, 
berkeluarga, berkelompok, interaksi dan kasih sayang, Kebutuhan akan penghargaan (Esteem), meliputi kebutuhan akan harga diri, status, prestise, respek dan penghargaan dari pihak lain, Kebutuhan aktualisasi diri (self-actualization), meliputi kebutuhan untuk memenuhi keberadaan diri (self fulfillment) melalui memaksimumkan penggunaan kemampuan dan potensi diri.

Terlihat bahwa kebutuhan manusia berdasarkan pada urutan prioritas, dimulai dari kebutuhan dasar, yang banyak berkaitan dengan unsur biologis, dilanjutkan dengan kebutuhan yang lebih tinggi, yang banyak berkaitan dengan unsur kejiwaan, dan yang paling tinggi yaitu aktualisasi diri tersebutlah yang dimaksud dengan kebutuhan spiritual. Jika dan hanya jika seluruh kebutuhan fisiologis dan kejiwaan seseorang tercapai, dia dapat mencapai tahap perkembangan tertinggi yaitu, aktualisasi diri. Maslow mendefinisikan aktualisasi diri sebagai sebuah tahapan spiritualitas seseorang, di mana seseorang berlimpah dengan kreativitas, intuisi, keceriaan, sukacita, kasih, kedamaian, toleransi, kerendah-hatian, serta memiliki tujuan hidup yang jelas, dan misi untuk membantu orang lain mencapai tahap kecerdasan spiritual ini. Menurut Maslow, pengalaman spiritual adalah peak experience, plateau - the farthest reaches of human nature.

Pengalaman spiritual adalah puncak tertinggi yang dapat dicapai oleh manusia serta merupakan peneguhan dari keberadaannya sebagai makhluk spiritual. Pengalaman spiritual merupakan kebutuhan tertinggi manusia. Bahkan Maslow menyatakan bahwa pengalaman spiritual telah melewati hierarki kebutuhan manusia, going beyond humanness, identity, self-actualization, and the like."

Pada akhirnya manusia sebenarnya membutuhkan spiritualitas sebagai bagian dalam hidupnya pada proses penemuan makna hidup. Kebutuhan manusia akan spiritualitas didasarkan pada;

1. Kebutuhan untuk mempertahankan atau mengembalikan keyakinan dan memenuhi kewajiban agama serta kebutuhan untuk mendapatkan maaf atau pengampunan, mencintai, menjalin hubungan, penuh rasa percaya denga Tuhan (Carson, 1989).

2. Kebutuhan untuk mencari arti dan tujuan hidup, kebutuhan untuk mencintai dan dicintai serta rasa keterikatan.

3. Kebutuhan untuk memberikan dan mendapatkan maaf.

\section{METODOLOGI PENELITIAN}

Penelitian ini menggunakan pendekatan deskripsif atau menggambarkan suatu masalah berdasarkan kajian pustaka yang telah ada pada literatur atau buku-buku panduan yang sesuai dengan penelitian ini. Dalam pelaksanaan penelitian studi kepustakaan ini penulis menggunakan study historis (dirasat alTarikhiyah).

Selain pendekatan di atas dan berdasar pada judul yang dibahas, maka pendekatan lain yang digunakanoleh penulis adalah sebagai berikut :

a. Pedekatan Paedagogik, yaitu metode pendekatan yang didasarkan kepada ilmu-ilmu pendidikan.

b. Pendekatan Psikologis, yaitu suatu hal yang didasarkan pada ilmu-ilmu yang mempelajari 
tentang kejiwaan manusia, yang dalam hal ini sebagai acuannya adalah psikologi.

c. Pendekatan Religius, yaitu menjadikan agama (Islam) sebagai paramameter dalam rangka pendidikan Islam.

\section{Kajian Teoretis dan Pembahasan}

1. Dimensi Spiritualitas Sebagai Puncak Kecerdasan

Temuan riset tentang kecerdasan spiritual ( $\mathrm{SI} / \mathrm{SQ}$ ) merupakan temuan yang menggemparkan karena temuan ini disebut-sebut sebagai the ultimate intelligence, puncak kecerdasan, setelah sebelumnya dunia psikologi dan pendidikan digemparkan oleh temuan terbaru Daniel Goleman tentang Emotional Intelligence (kecerdasan emosional/EQ). Menyahuti temuan tersebut maka di sana-sini senantiasa ramai diperbincangkan tentang kecerdasan emosional. Kajian intensif, diskusi, seminar, bahkan pendidikan dan pelatihan dalam skala besar diadakan hanya sekedar untuk menegaskan bahwa kecerdasan emosional sama ampuhnya dan bahkan terkadang lebih ampuh dari IQ (kecerdasan intelektual).

Namun, seperti terasa belum tuntas betul kajian tentang $E Q$, perhatian kita tiba-tiba dialihkan pada spiritual intelligence yang dalam buku ini disebut oleh Danah Zohar dan Ian Marshall sebagai the ultimate intelligence. Ini sungguh mencengangkan karena SI dipandang sebagai kecerdasan tertinggi manusia, yang dengan sendirinya melampaui segi-segi dua kecerdasan sebelumnya yakni kecerdasan intelektual dan kecerdasan emosional. SI menurut Zohar dan Marshall mengintegrasikan semua kecerdasan manusia, baik IQ maupun EQ.
Dengan spiritual intelligence kita diharapkan menjadi prototipe manusia yang benar-benar utuh dan holistik, baik secara intelektual, emosional, dan sekaligus secara spiritual. Apa yang diungkapkan Zohar dan Marshall tentang SI ini memang sangat menarik apalagi dengan membandingkannya dengan paradigma kecerdasan yang selama ini sudah jauh lebih populer dan mapan, yakni IQ dan EQ. Sebelum ditemukan EQ masyarakat mencitrakan bahwa IQ merupakan kunci kecerdasan untuk meraih masa depan, seseorang yang ber-IQ tinggi mempunyai masa depan cemerlang dan menjanjikan. Sampaisampai hal itu merasuk kuat ke dalam ingatan kolektif masyarakat: ber-IQ tinggi menjamin kesuksesan hidup; sebaliknya, ber-IQ sedangsedang saja, apalagi rendah, begitu suram masa depan hidupnya.

Setelah muncul paradigm EQ yang menghebohkan tersebut, dunia diramaikan lagi dengan temuan yang lebih komprehensif, yaitu kecerdasan spiritual. Keramaian ini meluas tidak saja di lembaga-lembaga keagamaan, namun juga di perusahaan-perusahaan besar yang berkeinginan menumbuhkan dan mengembangakan segi-segi kecerdasan spiritual pada staf dan karyawannya dalam aktivitas menjalankan rada bisnis mereka. Walaupun begitu untuk kasus Indonesia harus diakui walaupun penduduknya mayoritas muslim namun segmen masyarakat yang mengenal $\mathrm{SI}$ belum sebanding dengan jumlah tersebut. Hal ini dapat dimengerti karena SI wacana baru dalam masyarakat Indonesia. Hal ini sejalan dengan apa yang disinyalir dalam website www.amazon.com berkaitan dengan sebuah buku yang berjudul The Spiritual Intelligence Hanbook karya Paul 
Edwards (1999). Website ini mengemukakan komentar unik dan sedikit memprihatinkan "mayoritas pembaca memang belum pernah mendengar wacana SI, membacanya, apalagi berdiskusi dengan orang lain tentang kecerdasan spiritual ini ".

Kemunculan istilah $S Q / S I$ itu sendiri sampai saat ini memang masih menjadi kontroversi. Sebagian masyarakat masih belum menerima penggunaan kata Quotient yang dilekatkan dengan kata Spiritual (SQ). Mereka beralasan sebagai sesuatu yang transcendental, SQ dikatakan berbeda dengan IQ. Spiritual tidak dapat diukur berdasarkan perhitungan mental age dibagi cronological age dikalikan seratus. Di sini sangat beralasan jika buku buah karya Danah Zohar dan lan Marshall yang berjudul berjudul "SQ: Spiritual Intelligence" bukan SQ: Spiritual Quotient yang dijadikan rujukan dalam disertasi ini sebagai acuan teori dan kerangkan membangun kerangka pemikiran, disertai dengan pengakuan bahwa membicarakan kecerdasan spiritual merupakan sesuatu yang masih dianggap janggal oleh para akademisi, karena mereka menganggap ilmu pengetahuan belum memiliki perangkat untuk mempelajari sesuatu yang tidak mampu diukur secara objektif. Zohar dan Marshall mendapat dukungan Steven R. Covey (2004) yang menulis spiritual intelegence dengan SQ bukan SI dalam bukunya yang berjudul "The Seven Habits From Effectiveness to Greatness". Hal ini tentu saja mengundang pertanyaan, mengapa penulisan spiritual intelligence sering disingkat " $S Q$ bukan SI".

Sejumlah argumentasi yang mengantarkan spiritualitas disebut sebagai kecerdasan tentunya tidak terlepas dari hasil penelitian para ahli tentang akar kekuatan spiritualitas dalam otak manusia. Kajian neurologi, psikologi bahkan antropologi yang telah dilakukan menguatkan dugaan selama ini bahwa ada sebuah potensi dalam diri manusia yang terletak di saraf otaknya. Kerja keras yang menghebohkan dunia ini di antaranya adalah karya besar Michael Persinger (1990) dan V. Ramachandran (1997) yang menemukan bahwa dalam otak manusia ada "Titik Tuhan" (God Spot). Gagasan tentang spiritualitas sebagai kecerdasan berbasis otak merupakan hal yang sepenuhnya baru namun telah menjadi fenomena yang melampaui paradigma sains kognitif abad ke duapuluh, yang melengkapi berbagai kajian, hipotesis, konsep, pengetahuan, dan teori tentang manusia yang memang sudah tak terhitung jumlahnya. Karena pada dasarnya manusia tak pernah berhenti mencari dan menemukan hakikat eksistensinya yang memang masih menyimpan sejuta misteri. Persoalan tentang kelahiran dan kematian merupakan salah satu misteri yang selalu menarik untuk dikaji di samping realitas kebahagiaan dan kesedihan dan lain-lainnya yang kadangkala sulit untuk mampu dilogikakan.

Mencari pengertian atau definisi tentang kecerdasan spiritual bukanlah hal yang gampang. Karena istilah spiritual itu sendiri memang sulit didefinisikan, dan sangat multidimensi dan multiinterpretasi, sebagaimana yang dikatakan oleh West (2000) dan Cornet (1998) bahwa spiritualitas merupakan konsep yang sangat penting namun sulit untuk didefinisikan, walaupun menurut Bastaman (2007) sebenarnya istilah spirit atau spirituality bukanlah istilah baru, karena dalam setiap agama dan budaya kata itu selalu ada. Yang menjadi pertanyaan apakah 
spiritualitas itu selalu berkaitan dengan agama atau sebaliknya?

Untuk menjawab pertanyaan tersebut bukanlah hal mudah. Dalam beberapa literature spiritualitas dibedakan dengan agama (religion) bahkan dikatakan "spirituality is not religion". Spiritual adalah hidup dan sangat jauh dari tubuh (fisik) yang mengimplikasikan eksistensi jiwa (spirit of soul), dan ini sangat berbeda dengan definisi agama (oxford, 1980) yang mengimplikasikan keyakinan terhadap kekuatan kontrol superhuman yang lumrahnya diekspresikan melalui ritual penyembahan (worship). Bagi aliran yang memandang spiritualitas berbeda dengan religiusitas tentu akan memandang SI juga tidak terkait dengan kualitas keagamaan seorang penganut agama formal. Kecenderungan ini juga akan berimplikasi pada cara keyakinan dan keimanannya terhadap aspek-aspek agama, terutama tentang eksistensi Tuhan, kekuasaan, dan kedaulatannya terhadap manusia dan seluruh makhluk ciptaan-Nya. Agama formal dianggap sebagai perangkat aturan dan kepercayaan yang dibebankan secara eksternal, dan dipersepsi bersifat top-down, diwarisi dari pendeta, nabi, dan kitab suci atau ditanamkan melalui keluarga dan tradisi. Inilah juga yang diyakini oleh Zohar dan Marshall: SQ/SI tidak mesti berhubungan dengan agama. Karena menurut mereka SI mungkin menemukan pengungkapan melalui agama formal, tetapi agama tidak menjamin SI tinggi. Tak sedikit orang humanis, ateis, bahkan agnostic memiliki SI tinggi, namun sebaliknya banyak orang yang aktif dan fanatik beragama memiliki SI sangat rendah.

Adanya dikotomi antara spiritualitas dan religiusitas tentu sangat dipengaruhi cara pandang para ilmuwan terhadap manusia dan dinamika perilaku manusia. Konsep dan teorinya tentang manusia tentunya juga akan sangat dipengaruhi oleh falsafah tentang manusia dan agama itu sendiri. Ketidaksamaan paradigma berpikir tersebut tentu akan memberikan perbedaan pada wawasan, teori, konsep, metode, dan hasil-hasil penelitian penting tentang manusia dan keberagamaannya. Di sini dapat diambil sebuah pemahaman bahwa untuk memahami beragam jenis pengertian, konotasi, dan interpretasi SI perlu diadakan penelusuran yang mendalam terhadap akar pemikiran para pakar yang berteori tentang $\mathrm{SI}$, yakni ada yang berorientasi Antroposentrisme dan sebagian berorientasi Theosentrisme.

Zohar dan Marshall sebagai ilmuwan yang berorientasi Antroposentrisme sangatlah bisa dimengerti bila mengatakan bahwa SI tidak mesti berhubungan dengan agama, bahwa seorang humanis, atheis, atau agnostic dapat memiliki kecerdasan spiritual sangat tinggi; karena dalam konsepnya mereka menyandarkan semua teorinya pada teori Darwin tentang evolusi, prinsip-prinsip Psikoanalisa tentang id, ego, dan superego, dan psikologi humanistik tentang need actualization. Kecerdasan manusia menurut Zohar dan Marshall ada tiga macam dan semuanya berasal dari kode genetik serta ada sepanjang sejarah planet ini. Ketiga jenis kecerdasan tadi bekerja melalui dan dikendalikan oleh jaringan saraf dalam otak manusia. Ketiga bentuk kecerdasan tersebut adalah kecerdasan intelektual yaitu fungsi berpikir rasional, logis, dan tata-aturan yang dikenal dengan IQ, (2) kecerdasan emosional sebagai fungsi berpikir asosiatif, yang lumrahnya dibentuk 
oleh kebiasaan dan pengalaman dan dikenal dengan EQ, dan (3) kecerdasan spiritual sebagai fungsi berpikir kreatif, berwawasan, dan membuat atau mementahkan aturan, inilah yang dikenal dengan SQ/SI. Selanjutnya mereka menyimpulkan bahwa terdapat tiga proses psikologis dalam diri manusia yaitu (1) prapersonal yang bersifat instingtif dan asosiatif, yang disebut Freud "id" dan ini merupakan proses primer, (2) personal yaitu fenomena ego yang bersifat logis, rasional, dan linier yang kemudian disebut proses sekunder, dan (3) transpersonal yang bersifat unitif (integratif) sehingga melampaui diri ego menuju inti wujud yang kemudian disebut proses tersier (Daris Tamin, 2009: 37-38).

Dalam pandangan Zohar dan Marshall transendensi yang dianggap sebagai kualitas tertinggi dari kehidupan spiritual bukanlah sebagai sesuatu yang berada di balik materi sebagaimana anggapan para agamawan, tetapi merupakan sesuatu yang lebih sederhana namun sekaligus fundamental. Transenden merupakan sesuatu yang "beyond" untuk mengatasi masa kini, mengatasi rasa suka dan duka, bahkan untuk mengatasi diri pada saat ini dan membawanya melampaui batas-batas pengetahuan dan pengalaman untuk ditempatkan dalam konteks yang lebih luas; sesuatu yang memberi kesadaran tentang sesuatu yang luar biasa dan tak terbatas, baik itu sesuatu di dalam diri maupun di dunia sekitar. Transendensi boleh dikaitkan dengan Tuhan; boleh juga dikaitkan dengan pengalaman mistik; boleh juga untuk merasakan keindahan bunga, menikmati alunan musik, atau senyuman innocent dari seorang bayi.
Konsep Tuhan yang diwakili oleh pemahaman tentang "God Spof' dianggap sebagai kondisi perlu (necessary condition), bukan kondisi cukup (sufficient condition) bagi SI. Seseorang yang ber-SI tinggi mungkin tinggi pula beraktivitas yang berkaitan dengan God Spot namun tidak serta merta ia memiliki SI tinggi; karena untuk mencapai predikat orang yang berSI tinggi ia harus mampu mengintegrasikan seluruh bagian otaknya, seluruh aspek dirinya, dan seluruh aspek kehidupannya. Wawasan dan abilitas tentang God Spot harus dipadukan dengan emosi, motivasi, dan potensi kemudian membawanya dalam dialog dengan pusat diri.

Sebenarnya bila ditilik lebih lanjut pengaruh agama tentang Tuhan sebenarnya juga masuk dalam konsep SI Zohar dan Marshall, hanya saja konsep-konsep tersebut merujuk pada mitos-mitos agama-agama kultur (culture/natural religion) - agama hasil budaya manusia (agama ardhi/thabi'i) - seperti mitologi astrologi tentang asal usul manusia dalam agama Romawi dan Yunani; mitologi cakra sebagai gambaran tahapan perkembangan jiwa dalam "mengada" dan "menjadi" dalam agama Hindu; filosofi-filosofi dalam Tao Te Ching; juga dari pemikiranpemikiran ahli mistik agama Kristiani dan Yahudi yang menyatakan bahwa pusat jiwa adalah Tuhan dan mengenal diri sendiri akan mengenal Tuhan.

$$
\text { Dalam perspektif bimbingan dan }
$$
konseling manusia diyakini memiliki kemampuan untuk berpikir dan sosial yang tinggi, perasaan dan nafsu yang kuat, dan hati yang dalam. Sehingga ia mampu mengembangkan ilmu pengetahuan, mampu menata masyarakat yang rukun dan damai, mampu menikamati keindahan dengan art yang tinggi, mampu menghayati, 
menguasai, dan melaksanakan nilai-nilai moral, membedakan mana yang baik dan makan yang buruk. Namun manusia juga dilengkapi dengan nafsu, dorongan, dan keinginan yang terkadang mengarah kepada hal-hal yang negatif dan menyimpang dari aturan Sang pencipta.

$$
\text { Pada hakikatnya manusia adalah }
$$
makhluk beragama (homoreligius) dan fithrahnya manusia adalah makhluk spiritual yang selalu berupaya untuk senantiasa ada dalam kondisi mental yang sehat, agar hidup bahagia, lahir dan batin. la memiliki potensi kecerdasan spiritual yang sempurna untuk meraih 'spiritual wellness", yaitu kebahagiaan hidup sejati sebagai wujud karunia Ilahi. Untuk itulah layanan BK sebagai sebuah bentuk hubungan interpersonal seyogyanya berpegang pada nilai-nilai agama saat membantu, mengarahkan, dan memandu individu untuk mengembangkan kecerdasan spiritual hingga menggapai kehidupan bermakna dan kebahagiaan yang utuh dan terpadu. Karena nilai-nilai agama bersifat fundamental, mutlak, dan universal. Pendekatan BK yang berlandasakan agama untuk membantu mengoptimalkan segenap potensi spiritual diyakini tidak akan terjadi pertentangan. Sebab, pada hakikatnya antara keduanya menyentuh wilayah yang sama, yakni kesehatan mental. Keduanya juga melaju menelusuri fitrah manusia sebagai makhluk Sang Pencipta, saling menguatkan dalam kebersamaan mencari keselarasan hidup di alam semesta. Sejalan dengan kecenderungan berkembangnya konseling yang berbasis spiritual, Stanard et.al. (M. Surya, 2008:44) mengusulkan agar spiritualitas ini dijadikan sebagai angkatan kelima dalam konseling dan psikoterapi.

\section{Menjadi Cerdas Secara Spiritual}

Masyarakat yang hidup di zaman global ini dihadapkan dengan suatu krisis yang sangat kompleks dan multidimensional, yang segiseginya sudah merambah sudut kehidupan kita. Fakta ini sangat sulit bila hanya didekati sebagai bagian dari krisis intelektual dan moral saja. Namun jantung persoalan ini adalah krisis moral dan ini hampir merambah seluruh lini kehidupan kita, dan ini berasal dan bermuara pada "krisis spiritual" yang bercokol dalam diri kita. Penyakit spiritual merupakan akibat dari adanya masalah yang berhubungan dengan pusat diri terdalam, terpisah dari akar pengasuhan diri yang melampai ego personal dan budaya asosiatif. Inilah penyakit eksistensial.

Ada tiga sebab yang membuat seseorang yang dapat terhambat secara spiritual: (1) tidak mengembangkan beberapa bagian dari dirinya sendiri sama sekali, (2) telah mengembangkan beberapa bagian namun tidak secara proporsional atau dengan cara yang negatif atau destruktif, (3) bertentangannya atau buruknya hubungan antara bagian-bagian. Kondisi psikologis ini dirumuskan sebagai bentuk keterasingan, keterputusan diri, baik dengan diri sendiri, dari orang lain di sekelilingnya dan bahkan dari Tuhannya.

Jiwa merupakan saluran atau dialog dari yang batin pada yang lahir, pertemuan spontan dari pikiran rasional dan sadar dengan pusatnya dan dengan pusat dari seluruh keberadaan. Jika saluran/dialog ini macet, jiwapun hancur, kita menjadi terbelah dan secara spiritual sakit. Saat wawasan dan energi mengalir bebas melalui saluran dari dalam ke luar, jiwa dapat menyembuhkan kita. Kita menjadi terpusat, utuh. 
SI individu bekerja untuk menyatukan seluruh tingkatan keberadaan.

Penyakit spiritual disebut Jung sebagai penyakit eksistensial, di mana eksistensi diri kita mengalami penyakit alienasi (keterasingan diri) baik diri sendiri, lingkungan sosial, maupun teralienasi dari Tuhannya. Jung menaruh perhatian tinggi terhadap penyakit ini dan berkomentar bahwa beberapa psikoneurosis pada akhirnya harus dipahami sebagai "jiwa yang menderita" (a suffering soul) yang belum menemukan maknanya.

Gambaran umum Zohar dan Marshall tentang konsep spiritual sudah sangat membantu untuk mengidentifikasi sejauhmana kualitas spiritual individu dalam menjalani kehidupan ini. Apakah, misalnya kualitas perjalanan hidup individu selama ini sudah memenuhi kriteria di atas, baru sebatas separuh, atau jangan-jangan belum tersentuh sama sekali? Secara khusus, individu menguji kualitas SI secara lebih religious dan spiritual sehingga lebih terfokus. Ini bukan bermakna individu mendefinisikan kecerdasan spiritual individu, tetapi paling tidak dapat membantu individu untuk mendapatkan pegangan yang lebih baik mengenai kecerdasan spiritual itu. Sehingga individu bisa melatih dan akhirnya mampu menemukan dan memiliki kualitas SI yang prima. Karena pada dasarnya masing-masing dari individu adalah makhluk spiritual (spiritual being) yang memiliki potensi kecerdasan spiritual di berbagai level. Dan tentu individu harus senantiasa bergerak naik secara kualitatif, dari level terendah sampai tertinggi.

Untuk menjadi cerdas secara spiritual dalam budaya yang bodoh secara spiritual, maka individu seharusnya melakukan beberapa langkah utama yang dapat ditempuh adalah pertama mengenali diri sendiri. Karena orang yang sudah tidak mampu mengenali dirinya sendiri akan mengalami krisis makna hidup maupun krisis spiritual. Karenanya mengenali diri sendiri adalah syarat pertama untuk meningkatkan $\mathrm{SI}$ dan mampu menjadi cerdas secara spiritual dalam budaya yang bodoh secara spiritual. Kedua, melakukan introspeksi diri (pertobatan); ajukan pertanyaan pada diri sendiri: sudahkan perjalanan hidup dan karier saya berjalan atau berada di rel yang benar?" Barangkali saat individu melakukan introspeksi, individu menemukan bahwa selama ini individu telah melakukan kesalahan, kecurangan, atau kemunafikan terhadap orang lain. Ketiga, mengaktifkan hati secara rutin (mengingat Tuhan) karena Dia adalah sumber kebenaran tertinggi dan kepada Dia-lah individu kembali. Dengan mengingat Tuhan, hati individu menjadi damai. Hal ini membuktikan karena banyak orang yang mencoba mengingat Tuhan melalui cara berzikir, shalat tahajud di tengah malam, kontemplasi di tempat yang sunyi, mengikuti tasauf, bermeditasi, dll. Keempat, tentunya setelah individu mengingat Sang-Khalik, individu akan menemukan keharmonisan dan ketenangan hidup. Individu tidak lagi menjadi manusia yang rakus akan materi, tetapi dapat merasakan kepuasaan tertinggi berupa kedamaian dalam hati dan jiwa, hingga individu mencapai keseimbangan dalam hidup dan merasakan kebahagiaan spiritual.

Setidaknya untuk mengembangkan kecerdasan terbagi menjadi tiga komponen, Spiritual Thoughts, yang berisi renunganrenungan tentang makna dan hakikat berbagai hal yang bersifat spiritual. Bagian Kedua adalah 
Spiritual Workouts, yang berisi tentang kebiasaan harian yang perlu individu lakukan untuk sedikit demi sedikit meningkatkan kecerdasan spiritual individu. Tujuan dari berbagai latihan (exercises) yang diuraikan dalam bab-bab di bagian kedua ini adalah untuk mencapai tahap meditatif melalui serangkaian latihan seperti: strecthing, deep breathing, detoxifying, relaxing at alpha state, dan meditasi. Dan ketiga adalah Spiritual Behaviors mengenai perilaku spiritual yang perlu individu kembangkan dalam kehidupan individu seperti: pengendalian diri, beramal dan mengucap syukur, rela memaafkan, pasrah, rendah hati, tidak cemas, menjalin hubungan baik dan mencintai pekerjaan individu.

Oleh karena itu, Danah Zohar memberikan gambaran untuk menuju kecerdasan tersebut agar terhindar dari penyakit kekeringan spiritual. Jika sejak masih muda seseorang sudah mampu menemukan jalannya sendiri hal itu merupakan keberuntungan. Karena pada hakekatnya mereka sudah memiliki SI yang tinggi, dan merupakan langkah pertama untuk meningkatkan SI. Namun tidak semua orang mampu seperti itu karena terkadang ada yang terhambat karena salah niat atau korban keadaan dan lingkungan. Sehingga mereka tidak menemukan jalan kehidupan yang cerdas secara spiritual. Setiap jenis kepribadian bisa meningkatkan SI-nya, yang penting setiap aktivitas yang dilakukan selalu timbul dari suatu hasrat yang terpusat, dari motivasi dan nilai-nilai kehidupan yang paling dalam. Adapun jalan yang dapat ditempuh untuk meningkatkan SI adalah Jalan Tugas, jalan Pengasuhan, Jalan Pengetahuan, Jalan Perubahan Pribadi, Jalan Persaudaraan, dan Jalan Kepemimpinan yang
Penuh Pengabdian. Dengan enam jalan itu pada dasarnya ada tujuh langkah praktis untuk menjadi cerdas secara spiritual yaitu: pertama; menyadari di mana saya sekarang, kedua; merasakan dengan kuat bahwa saya ingin berubah, ketiga; merenungkan apakah pusat saya sendiri dan apakah motivasi saya yang paling dalam, keempat; menemukan dan mengatasi rintangan, kelima; menggali banyak kemungkinan untuk melangkah maju, keenam; menetapkan hati saya pada sebuah jalan, dan ketujuh; tetap menyadari bahwa ada banyak jalan. Untuk meningkatkan SI satu hal yang perlu digarisbawahi adalah bahwa "Semua Jalan Menuju dan Berasal dari Pusat".

\section{Membangun Spiritualitas Manusia}

Struktur kepribadian manusia, yang di dalamnya terungkap berbagai fakultas spiritual, menjadi kajian para sufi dan banyak pemikir muslim lainnya. Fakultas-fakultas spiritual itu diteliti, karena dengannya para pencari kebenaran melakukan aktivitasnya, baik dalam pengertian melakukan pendakian spiritual ataupun dalam meningkatkan fakultas-fakultas spiritual itu sendiri. Mereka juga tertarik dengan sebuah hadis Nabi yang sangat terkenal dalam kalangan tradisi sufistik: "Barangsiapa yang mengenal dirinya, maka ia mengenal Tuhannya." Mereka berupaya menemukan asosiasi-asoiasi yang mungkin dalam keterkaitan manusia dengan Tuhan dan dengan alam semesta (kosmos), dengan maksud untuk memperoleh pemahaman yang lebih baik tentang tiga realitas: Tuhan sebagai metakosmos, alam semesta sebagai makrokosmos, dan manusia sebagai mikrokosmos.

Jika dalam perspektif kosmologi spiritual kosmos dibedakan dalam dua tataran, yaitu kosmos spiritual (alam ruhani) dan kosmos fisikal 
(alam materi), maka dalam dunia manusia (mikrokosmos) terdapat pula padanannya, yaitu dua unsur kepribadian manusia, yaitu jiwa (ruhani) dan badannya. Ruhani manusia membentuk hubungan keserasian dengan bagian alam spiritual dari kosmos, dan badan manusia membentuk hubungan keserasian dengan alam fisik kosmos. Lebih dari itu, asosiasi-asosiasi yang dapat dibuat dalam hubungan dengan realitasrealitas itu jauh lebih rumit dan mencakup semuanya, misalnya keserasian antara format fisik manusia dengan format ruhaminya. Dengan demikian, sifat-sifat dan karakteristik alam spiritual selaras pula dengan alam materi, dan dunia jiwa manusia juga selaras dengan karakteristik fisiknya. Hubungan-hubungan ini tentunya juga akan dengan sendirinya selaras dengan Tuhan, sebagaimana diungkapkan dalam al-Qur'an bahwa Dialah yang zahir dan batin. Keselarasan ini menyiratkan adanya keteraturan di mana saja, dan itulah rancangan besar Allah, yang mau tidak mau harus dapat disimpulkan memiliki signifikansi yang luar biasa bagi kehidupan manusia. Allah menciptakan alam semesta dan kemudian menyempurnakannya, boleh jadi penyempurnaan itu berkaitan dengan penciptaan manusia yang memiliki kualitas-kualitas ilahiah dan kosmologis secara menyeluruh (jam'iyyah), dan seperti halnya Tuhan, manusia juga menjadi pusat dalam keteraturan alam semesta.

Konsekuensi dari kesimpulan penalaran ini adalah keharusan manusia untuk mempertahankan keselarasan dalam hubunganhubungan kosmologis, di mana ia menjalankan peran sentralnya. Keselarasan yang pertama kali harus diupayakan adalah keselarasan dalam diri manusia sendiri, yang mencakup keselarasan dalam struktur ruhaninya yang merupakan lokus dari segala upayanya. Keselarasan dan juga keseimbangan ruhani diperlukan, sekurangkurangnya untuk mewujudkan superioritas jiwa atau ruhani manusia atas badan, yang dengan sendirinya akan berarti kekuatan jiwa akan dapat mengendalikan gerakan badan. Jika dikaitkan dengan bentuk-bentuk hubungan analogis dalam kosmos, yang berlaku baik dalam dunia fisik mapun dalam dunia ruhani, berupa hubungan atas-bawah atau hubungan aktif-reseptif, maka dalam diri manusia terdapat juga bentuk-bentuk hubungan seperti itu. Hubungan seperti ini dapat, misalnya, disimpulkan dari sebuah hadis Nabi yang menyebutkan adanya segumpal daging yang disebut jantung yang keberadaannya begitu berpengaruh kepada kualitas-kualitas fisik, yang jika ia sehat akan sehatlah seluruh anggota badan, dan sebaliknya. Dalam dunia ruhani atau dunia jiwa manusia, keadaan ini pun terjadi, di mana hati dipandang sebagai pusat acuan aktivitas ruhani, yang posisinya sama esensialnya dengan jantung bagi tubuh.

\section{KESIMPULAN}

Pada akhirnya, penulis dapat mengatakan proses yang dilakukan sekarang mampu memberikan dampak yang efektif dan memberikan kontribusi yang nyata bagi kehidupan individu.

Upaya yang dilakukan sekarang ini memberikan sebuah pencerahan yang baik terhadap setiap orang yang ada di dalamnya. Oleh karena itu, kegiatan semacam ini harus terus dilakukan secara berkelangsungan dan konsisten. 


\section{DAFTAR PUSTAKA}

Abdul Munir Mulkhan, (2002) Nalar Spiritual Pendidikan Solusi Problem Filosofis Pendidikan, Yogyakarta : Tiara Wacana.

Ali, Abdullah Yusuf. (1989). The Holy Qur'an: Text, Translation and Commentary Brentwood, Maryland, USA: Amana Corporation).

Ali, Yunasril. (2002). Jalan Kearifan Sui: Tasawuf sebagai Terapi Derita Manusia Jakarta: Serambi IImu semesta.

Djaenudin, Djudjun, S.Th. Artikel (1980.): Spiritual Quoetient (Kecerdasan Spiritual). Jakarta : Lembaga Alkitab Indonesia. Alkitab. Bogor.

Dahlan, M.D. (2002). "Warna Arah Bimbingan dan Konseling Alternatif di Era Globalisasi." Jurnal Psikopedagogia, Vol. 2 No. 3, Mei 2002,139-155. Dahlan, M.D. (2003). "Perspektif Profesi Bimbingan Konseling Berbasis Values dalam Pengembangan Fitrah Manusia."

Gerlald Corey. (2003). Teori dan Praktek Konseling dan Psikoterapi (Terj. E. Koswara), Bandung : Refika

Zohar, Danah dan lan Marshall. (2001) SQ : Memanfaatkan Kecerdasan Spiritual Dalam Berpikir Integralistik dan Holistik Untuk Memaknai Kehidupan. Bandung : Mizan 